Gorontalo
Jounalof Public Administration Studies

\title{
Implementasi Kebijakan dalam Meningkatkan Sumber Daya Aparatur Pemerintahan di Kantor Kecamatan Bintauna Kabupaten Bolmong Utara
}

\author{
Sarfan Tabo \\ Program Studi Administrasi Publik Universitas Gorontalo \\ sarfantabo@yahoo.com
}

\begin{abstract}
This study aims to determine or analyze the implementation of government policy in Bintauna District Office. Through research observation will be able to get a picture or explanation about the implementation of policy towards empowerment of government apparatus in District Office of Bintauna. This research is a descriptive research concerning two main things that is as the main insight, the first focuses on the actual problems that come from the apparatus that became the respondent. This objective and effort is to optimally capture the facts in the field so as to obtain data from this research proportionally and reveal various problems related to the government apparatus in implementing government policy concepts in Bintauna District Office of North Bolmong Regency as well as the extent of their implementation. From the research that has been done found the lack of attention, coaching as well as direction by the leadership on the discipline of the apparatus. But if judged from the overall results, it can be concluded that the policies implemented by the district government succeed. Because if calculated from the percentage of frequencies in the table recapitulation, the percentage of efforts to improve the quality of the apparatus is above average.
\end{abstract}

Keywords: policy implementation; aparatur resources.

\begin{abstract}
ABSTRAK
Penelitian ini bertujuan untuk mengetahui atau menganalisis pelaksanaan kebijakan pemerintah di Dinas Kabupaten Bintauna. Melalui observasi penelitian akan dapat memperoleh gambaran atau penjelasan tentang implementasi kebijakan terhadap pemberdayaan aparatur pemerintah di Kantor Kecamatan Bintauna. Penelitian ini merupakan penelitian deskriptif mengenai dua hal utama yaitu sebagai wawasan utama, yang pertama berfokus pada masalah-masalah aktual yang berasal dari aparatur yang menjadi responden. Tujuan dan upaya ini adalah untuk secara optimal menangkap fakta-fakta di lapangan untuk memperoleh data dari penelitian ini secara proporsional dan mengungkapkan berbagai masalah terkait dengan aparatur pemerintah dalam melaksanakan konsep kebijakan pemerintah di Kantor Bintauna Kabupaten Bolmong Utara serta tingkat implementasi mereka. Dari penelitian yang telah dilakukan ditemukan kurangnya perhatian, pembinaan serta arahan oleh pimpinan pada disiplin aparatur. Tetapi jika dinilai dari hasil keseluruhan, dapat disimpulkan bahwa kebijakan yang diterapkan oleh pemerintah kabupaten berhasil. Karena jika dihitung dari persentase frekuensi dalam tabel rekapitulasi, persentase upaya untuk meningkatkan kualitas aparat berada di atas ratarata.
\end{abstract}

Kata Kunci: implementasi kebijakan; sumber daya aparatur. 


\section{PENDAHULUAN}

Kebijakan pemerintah lahir dan di tuntut, dalam rangka pengembangan sumber daya manusia, karena pengembangan sumber daya manusia merupakan kunci keberhasilan dari otonomi daerah yang bertanggung jawab. Dan kebijakan yang dikeluarkan dalam rangka pembinaan atau pengembangan sumber daya manusia yang berkualitas antara lain pendidikan dan pelatihan. Hal tersebut memang sudah menjadi tanggung jawab pemerintah sebagai mana dinyatakan dalam UU No 20. Thn. 2003 Tentang Sistem Pendidikan Nasional.

Kabupaten Bolmong Utara sebagai salah satu daerah yang merupakan pelaksana utama kebijakan otonomi di tingkat daerah sangat memperhatikan aspek peningkatan kualitas sumber daya pelaksana pembangunan. Implementasi dari kebijakan tersebut diantaranya adalah peningkatan kualitas aparatur pemerintah dengan melakukan kontrak kinerja dengan satuan dinas/badan/kantor pemerintah dan unit kerja pemerintahan lainnya. Hal ini lebih dimaksudkan untuk memberikan target dan capaian maksimal dari pelaksanaan tugas pokok dan fungsi satuan kerja pemerintah daerah Kabupaten Bolmong Utara.

Berdasarkan gambaran di atas penulis merasa tertarik untuk meneliti lebih jauh tentang penerapan dari pada kebijakan yang di keluarkan oleh pemerintah terhadap pengembangan sumber daya manusia dalam hal ini aparatur pemerintah yang ada di daerah dengan memilih lokasi penelitian di Kantor Kecamatan Bintauna.

\section{KAJIAN TEORI}

\subsection{Kebijakan Pemerintah}

Kata kebijakan adalah terjemahan dari Bahasa Inggris "policy" dan kita tidak dapat memisahkan kata policy itu dalam konteksnya dengan politik, karena pada hakekatnya proses pembuatan kebijakan itu adalah proses politik. Beberapa pengertian kebijakan yang didefinisikan oleh beberapa ahli yakni : Lasswell dan Kaplan mengartikan kebijakan yaitu suatu program pencapaian tujuan, nilai-nilai dan tindakan-tindakan yang terarah. Sementara itu, Friendrich mendefenisikan kebijakan sebagai serangkaian tindakan yang diusulkan seseorang, kelompok atau pemerintah dalam suatu lingkungan tertentu dengan menunjukkan kesulitan-kesulitan dan kemungkinankemungkinan usulan kebijaksanaan tersebut dalam rangka mencapai tujuan tertentu.

Anderson mendefenisikan kebijakan yaitu serangkaian tindakan yang mempunyai tujuan tertentu yang diikuti dan dilaksanakan oleh seorang pelaku dan sekelompok pelaku guna memecahkan suatu masalah tertentu. Mac Rea dan Wilde memberikan pengertian kebijakan sebagai serangkaian tindakan yang dipilih dan mempunyai arti penting dalam mempengaruhi sejumlah besar orang.

Menurut Lasswell dan Kaplan kedua ahli ini menekankan bahwa kebijakan itu berisi suatu program kegiatan yang mengandung nilai-nilai tertentu dan kegiatannya diarahkan untuk mencapai suatu tujuan tertentu. Kebijakan sama artinya (identik) dengan suatu program yang berorientasi pada tujuan tertentu. Friendrich lebih Manajemen sumber daya manusia yaitu suatu gerakan pengakuan terhadap pentingnya unsur manusia sebagai sumber daya manusia yang cukup potensial, yang perlu dikembangkan sedemikian rupa sehingga 
mampu memberikan kontribusi yang maksimal bagi organisasi dan bagi pengembangan dirinya (Faustino Cardoso Gomes 2003 : 3).

\subsection{Manajemen Sumberdaya Manusia}

Sumber Daya Manusia (SDM) secara umum merupakan satu-satunya sumber daya yang memiliki akal, perasaan, keinginan, kemampuan, keterampilan, pengetahuan, daya dan karya. Satu-satunya sumber daya yang memiliki ratio, rasa, dan karsa. Semua potensi sumber daya manusia tersebut sangat berpengaruh terhadap upaya organisasi dalam pencapaian tujuannya. Betapapun majunya teknologi, berkembangnya informasi, tersedianya modal dan memadainya bahan, namun jika tanpa sumber daya manusia maka akan sulit bagi organisasi untuk mencapai tujuannya. Betapapun bagusnya perumusan tujuan dan rencana organisasi, agaknya hanya akan sia-sia belaka jika unsur sumber daya manusianya tidak diperhatikan apalagi kalau ditelantarkan.

Sumber daya manusia adalah sumber daya yang cukup potensial, yang perlu dikembangkan sedemikian rupa sehingga mampu memberikan kontribusi yang maksimal bagi organisasi dan bagi pengembangan dirinya.

\subsection{Aparatur}

Menurut W.J.S Purwadarminta bahwa kata aparatur berasal dari kata alat kemudian menjadi kata "Aparat" dan setelah dikembangkan menjadi kata aparatur yang berarti pegawai-pegawai, misalnya : apratur negara, berarti alat negara. Aparatur negara adalah keseluruhan pejabat dan lembaga, negara serta pemerintahan, sebagai abdi negara, yang bertugas dan bertanggung jawab atas penyelenggaraan negara dan pembangunan serta senantiasa mengabdi dan setia kepada kepentingan umum dan nilai-nilai, cita-cita perjuangan bangsa dan negara berdasarkan pancasila dan Undang-Undang Dasar 1945.

Melihat luasnya pengertian dan adanya mecam-macam istilah terhadap aparatur ini, dalam tulisan ini dapat dipakai istilah terhadap aparatur pemerintahan diartikan sebagai abdi negara dan abdi masyarakat yang melayani, mengayomi dan menumbuhkan prakarsa serta partisipasi masyarakat dalam pembangunan.

Aparatur biasa dikatakan perangkat atau alat yang bekerja pada suatu instansi pemerintah atau negara. Pada prinsipnya bahwa kemampuan kerja bagi aparatur pemerintah tercermin pada kemampuan secara pribadi maupun organisasi, keinginan secara pribadi bisa didorong oleh keinginan untuk mencapai imbalan materil atau imbalan immateril berupa penghargaan, dan lain sebagainya. Sedangkan keinginan secara organisasi, karena didorong oleh pencapaian target yang telah ditetapkan oleh organisasi.

\section{METODOLOGI PENELITIAN}

\subsection{Sifat Penelitian}

Penelitian ini bersifat deskriptif yang dilaksanakan dengan menggunakan metode survey, penelitian deskriptif adalah penelitian yang memuat panca indera secara sistematis, faktual, dan akurat mengenai fakta-fakta dan sifat-sifat populasi daerah tertentu. Yousda dan Abidin (1994:21) mengemukakan bahwa penelitian dengan metode deskriptif di lakukan jika peneliti ingin menjawab persoalan-persoalan tentang fenomena yang ada atau sedang berlaku sekarang. 
Penelitian deskriptif yang dimaksud menyangkut dua hal pokok yaitu sebagai wawasan utamanya, yang pertama memusatkan pada masalah-masalah yang aktual yang bersumber pada aparatur yang menjadi responden. Tujuan dan upaya ini adalah menjaring secara optimal fakta di lapangan sehingga perolehan data dari penelitian ini secara proporsional dan mengungkapkan berbagai permasalahan yang kaitannya dengan aparatur pemerintah dalam melaksanakan konsep-konsep kebijakan pemerintah di Kantor Kecamatan Bintauna Kabupaten Bolmong Utara sekaligus sejauhmana pelaksanaannya. Kedua faktor tentang masalah yang diselidiki sebagaimana adanya diikutkan dengan interpretasi secara rasional dalam berbagai lapangan.

\subsection{Lokasi Penelitian}

Berdasarkan latar belakang masalah dan kerangka pemikiran, maka objek penelitan adalah aparatur pemerintah dalam implementasi kebijakan yang lokasi penelitiannya di Kantor Kecamatan Bintauna.

\subsection{Fokus Penelitian}

Berdasarkan masalah serta tujuan penelitian maka yang menjadi fokus dalam penelitian ini adalah penerapan kebijakan pemerintah di Kantor Kecamatan Bintauna Kabupaten Bolmong Utara.

\subsection{Populasi dan Sampel}

Populasi dalam penelitian ini adalah seluruh aparatur pemerintah yang ada di Kantor Kecamatan Bintauna Kabupaten Bolmong Utara yang dianggap dapat memberikan informasi yang valid mengenai permasalahan yang diteliti. Mengingat jumlah, contoh atau populasi yang kecil, maka penulis menjadikan semua populasi sebagai informasi penelitian. Karena dalam penelitian ini tidak dilakukan sampling, dan penelitian ini merupakan penelitian populasi.

\subsection{Variabel Penelitian dan Definisi Operasional}

Dalam penelitian ini terdiri dari 2 variabel yaitu kebijakan pemerintah sebagai variabel independent di mana hal ini berhubungan dengan pendidikan dan pelatihan. Sedangkan variabel dependentnya kualitas sumber daya aparatur sebagai variabel terpengaruh yang berhubungan dengan penerapan kegiatan, aktivitas dan tindakan. Adapun veriabel tersebut dapat didefinisikan sebagai berikut:

1. Kebijakan pemerintah. Kebijakan pemerintah adalah suatu keputusan yang berupa aturan-aturan, yang diambil berdasarkan pertimbanganpertimbangan tertentu, dalam hal ini bersinggungan dengan aparatur. Kebijakan disini diambil sehubungan dengan upaya peningkatan kualitas sumber daya aparatur. Kebijakan pemerintah dapat dioperasionalkan melalui pendidikan dan pelatihan berupa prajabatan dan diklat.

2. Kualitas Sumber Daya Aparatur dapat dikualifikasikan sebagai berikut :

- Motivasi

- Disiplin

- Kejujuran

- Produktifitas

- Loyalitas

- Hubungan Kerja Yang Baik 
- Kreativitas

- Tanggung Jawab

- Potensi Dan Skill

- Pelayanan Masyarakat

Indikator-indikator pada 2 (dua) variabel diatas ini nantinya akan menjadi bagian dari penelitian mencari hubungan-hubungannya.

\subsection{Sumber Data}

Dalam penelitian ini penulis menggunakan instrumen penelitian/ pengumpulan data dengan menggunakan beberapa cara antara lain sebagai berikut :

1. Data sekunder, data yang digunakan adalah data yang sudah ada pada lokasi penelitian yang dapat berupa dokumen-dokumen yang berhubungan dengan permasalahan yang akan diteliti, literatur-literatur dan laporan penelitian.

2. Data primer, data yang diperoleh langsung dari responden dan informan di lokasi penelitian melalui quisioner, wawancara, maupun dokumentasi.

\subsection{Teknik Pengumpulan Data}

Proses pengumpulan data dalam penelitian ini meliputi tiga tahap yaitu:

1. Wawancara mendalam, bertujuan untuk memperoleh data dan informasi kualitatif secara langsung dari sumber data. Sedangkan teknik wawancara bersifat terbuka dengan tujuan agar responden dapat memberikan jawaban dan pandangan seluas-luasnya. Dan agar wawancara tetap berada dalam konteks penelitian maka wawancara disertai pedoman wawancara (interviewguide) yang dapat berkembang sesuai dengan kebutuhan penelitian ini.

2. Dokumentasi, engan cara mengumpulkan data sekunder (Peraturan perundang-undangan dan data relevan lainnya bagi penelitian ini) yang berfungsi untuk memperkuat data primer.

3. Penelitian Lapangan, guna melengkapi hasil penelitian dan pengumpulan data, maka dilakukan observasi kelapangan untuk melakukan pengamatan langsung kepada objek penelitian.

\subsection{Teknik Analisa Data}

Teknik Analisa data yang di gunakan untuk memperoleh gambaran mengenai keadaan setiap Variabel penelitian secara sendiri-sendiri (tunggal) analisis secara kualitatif dengan dukungan data kuantitatif yang hasilnya akan di paparkan dalam bilangan prosentase dan tabel distribusi frekwensi, Sugiono (2001 : 73). Dari konstruksi penelitian deskriptif tersebut, maka analisa data dalam penelitian ini, yaitu di mana instrumen penelitian yang diperoleh dari data-data melalui kuisioner dianalisa dalam bentuk tabel dan frekuensi yang kemudian diprosentasekan, setelah itu kemudian dianalisa kecenderungan atas jawaban yang ada. Adapun rumus yang digunakan sebagai berikut :

$$
\begin{aligned}
P=\frac{F}{N} 100 \% & \\
\text { Di mana : } & \mathrm{P}=\text { Prosentase } \\
& \begin{array}{l}
\mathrm{F}=\text { Frekuensi jawaban } \\
\text { N=Jumlah sampel (responden) }
\end{array}
\end{aligned}
$$




\section{HASIL PENELITIAN DAN PEMBAHASAN}

Salah satu bentuk upaya peningkatan kualitas sumber daya aparatur yaitu dengan adanya kerja sama dan dorongan dari seorang pemimpin. Karena segala daya upaya yang di arahkan untuk menjaga dan memelihara suatu hal agar dapat berjalan dengan baik atau dapat di tingkatkan hasilnya maka secara operasional memiliki indikasi adanya pemimpin dengan tindakan-tindakan antara lain:

\subsection{Pimpinan Memotivasi Aparat}

Salah satu upaya pimpinan dalam meningkatkan kualitas sumber daya aparatur dilaksanakan melalui pemberian motivasi. Hal ini didukung dengan pernyataan $76,92 \%$ dari informan yang menyatakan selalu mendapatkan motivasi atau dorongan dari pimpinan dan $23,08 \%$ informan yang menyatakan kadang-kadang.

\subsection{Pimpinan Memperhatikan Tingkat Disiplin Aparat}

Disiplin merupakan suatu hal yang tidak bisa di sepelekan, karena dari disiplin ini juga kita bisa mengukur tingkat keaktifan dari aparatur. Tapi dari tabel diatas yang menyatakan pimpinan selalu memperhatikan tingkat disiplin aparat hanya $61,54 \%$ saja, sedangkan $38,46 \%$ menyatakan kadang-kadang.

\subsection{Pimpinan Memperhatikan Tingkat Kejujuran Aparat}

Tingkat kejujuran tidak luput dari perhatian pimpinan, dimana dalam setiap organisasi dibutuhkan saling keterbukaan sikap, baik antara atasan dan bawahan maupun antara sesama aparat. Jika di lihat dari tabel diatas dapat disimpulkan bahwa perhatian pimpinan terhadap tingkat kejujuran aparat cukup tinggi, hal ini divonis berdasarkan jawaban dari responden dimana didapatkan 76,92\% yang menyatakan selalu dan 19,23\% menyatakan Kadangkadang sedangkan 3,85\% menyatakan tidak pernah.

\subsection{Pimpinan Memperhatikan Peningkatan Produktifitas Kinerja Aparat}

Produktifitas merupakan salah satu ukuran yang perlu diperhatikan dalam upaya meningkatkan kualitas sumber daya aparatur, dimana dalam hal ini kinerja aparat selalu diprioritaskan, dan dari hasil penelitian yang didapatkan dari responden sungguh membanggakan karena dari sekian responden menyatakan pimpinan selalu memperhatikan tingkat produktifitas aparat didapatkan jawaban sebanyak $88,46 \%$ dan 11,54 menyatakan kadang-kadang.

\subsection{Pimpinan Memperhatikan Loyalitas Aparat}

Loyalitas adalah bukti pengabdian terhadap apa yang telah di bebankan atau yang telah di percayakan pada setiap aparat yang ada dalam suatu instansi, selain itu juga loyalitas merupakan salah satu penilaian terhadap kepengikutan aparat pada atasan dan dari hasil penelitian didapatkan 80,77 yang menyatakan bahwa pimpinan selalu memperhatikan loyalitas aparat, sedangkan yang menyatakan kadang-kadang 19,23\%.

\subsection{Penciptaan Suasana Hubungan Kerja Harmonis Antara Aparat}

Dalam setiap organisasi dibutuhkan kerja sama antara bawahan dengan atasan dan juga antara sesama aparatur, oleh karena itu hubungan keakraban dan pentingnya komunikasi antara sesama aparatur perlu diperhatikan, tetapi jika diamati dari hasil yang ada pada tabel diatas hubungan antara aparatur bisa di katakan harmonis, karena peneliti melihat tanggapan responden yang cukup tinggi yaitu $92,31 \%$ sedangkan yang menyatakan kadang-kadang hanya $7,69 \%$. 


\subsection{Kreatifitas dan Partisipasi Kerja Aparat Menjadi Perhatian Untuk di Tingkatkan}

Kreatifitas dan partisipasi kerja aparat yang dikatakan perlu perhatian karena hal ini merupakan salah satu tuntutan pada setiap aparat dalam membantu melancarkan pelaksanaan tugas-tugas yang ada, dan melihat tanggapan responden yang cukup tinggi yaitu 84,62 \% maka tingkat kreatifitas aparat bisa dikatakan memuaskan, dan dari sekian responden hanya 15,38 yang menyatkan kadang-kadang.

\subsection{Pimpinan Membina Aparat Untuk Bertanggung Jawab}

Pembinaan sebagai proses dan upaya dalam bentuk perbuatan dan tindakan yang dilakukan dengan maksud menjaga, memelihara sesuatu agar berjalan dengan maksimal dan jika perlu ditingkatkan hasilnya. Pembinaan lebih mengarah pada upaya atau proses yang ditujukan pada manusia agar tetap sesuai menjalankan tugas dan fungsinya.

Dimana hal ini diterapkan dalam pembinaan tanggung jawab. Karena setiap aparat telah diberikan kepercayaan dalam mengelola dan menjalankan tugas sesuai dengan fungsinya, untuk itu di butuhkan tanggung jawab yang besar dalam pelaksanaannya. Dari hasil pengamatan peneliti didapati bahwa pembinaan tanggung jawab aparat oleh pimpinan sangat tinggi yaitu $96,15 \%$ sedangkan yang menyatakan kadang-kadang hanya 3,85\% saja.

\subsection{Pemimpin Memperhatikan Kemampuan Dan Keterampilan Kerja}

Dalam perekrutan aparat kemampuan dan keterampilan merupakan salah satu prasyarat yang perlu diperhitungkan, karena tanpa keterampilan dan kemampuan kerja tidak akan tercapai apa yang menjadi tujuan organisasi. Tabel di atas menunjukan frekuensi jawaban yang menyatakan pimpinan selalu memperhatikan kemampuan dan keterampilan kerja aparat adalah $73,08 \%$ dari 26,92\% pernyataan responden yang menyatakan kadang-kadang.

\subsection{Pimpinan Memperhatikan Aparat dalam Pelayanan Masyarakat}

Pelayanan masyarakat bukan hanya di jadikan topik utama dalam setiap penjabaran wacana tetapi realisasinya yang dituntut. Karena dimana-mana hal ini selalu menjadi prioritas utama dalam pelaksanaan suatu program atau kegiatan di berbagai instansi, jika dilihat dari angka yang tercantum pada diatas bahwa aparat mampu mengimbangi pelayanan terhadap masyarakat yang didukung dengan angka $80,77 \%$ dari hasil yang di paparkan oleh responden, sedangkan yang menyatakan kadang-kadang hanya $7,69 \%$ dari sekian responden yang ada.

Dari hasil kesimpulan data diatas kita bisa melihat bahwa dari frekuensi yang ada, maka yang porsentasi yang mendominasi adalah tingkat pembinaan tanggung jawab terhadap aparat yang porsentasinya adalah 96,15\%, sedangkan minimalisasinya adalah perhatian pimpinan terhadap tingkat disiplin aparat yang di lihat dari porsentasenya hanya sekitar $61,54 \%$ saja.

Motivasi dapat memacu semangat seorang pegawai untuk berprestasi yang tergolong pada achievement motivation, motif yang mendorong serta menggerakkan seseorang untuk berprestasi dengan selalu menunjukkan peningkatan ke arah standard excellence, sebagaimana yang dikemukakan Mc Clelland dalam Sulistiyani dan Rosidah (2003 : 194).

Sistem pelaporan prestasi pegawai dalam bentuk buku kinerja melibatkan dua pihak, yaitu pihak yang dinilai dan yang menilai. Ada beberapa teknik untuk memetakan dua pihak penilai dan yang dinilai tersebut, yaitu atasan 
menilai bawahan, bawahan menilai atasannya atau setiap pegawai menilai teman kerjanya sendiri secara horisontal. Melihat struktur pemerintahan yang hirarkis maka teknik atasan mengevaluasi bawahan sangat mungkin diterapkan. Atasan sebagai sumber feedback menginformasikan prestasi atau kinerja bawahannya. Pegawai yang mempunyai prestasi kerja cukup baik diberikan penghargaan (reward) yang bisa memotivasi pegawai lain untuk berprestasi.

\section{PENUTUP}

\subsection{Kesimpulan}

Dari pembahasan dan hasil penelitian yang telah di jabarkan diatas maka peneliti dapat menyimpulkan bahwa kurangnya perhatian, pembinaan sekaligus pengarahan oleh pimpinan pada tingkat kedisiplinan aparat. Hal ini bisa dilihat dengan jelas pada tabel kuisioner tentang peran aktif pimpinan dalam memperhatikan tingkat kedisiplinan aparat, juga terpapar dengan jelas pada rekapitulasi tabel. Jika dalam bidang pembinaan tanggung jawab oleh pimpinan bisa di katakan hampir mendekati sempurna, pernyataan ini merupakan akumulasi dari hasil yang ada pada porsentasi frekuensi yang hampir maksimal yaitu adalah $96,15 \%$. Tetapi sangat di sayangkan karena hal ini tidak di imbangi dengan pembinaan pada tingkat kedisiplinan.

Tetapi jika di nilai dari hasil keseluruhan peneliti bisa menyimpulkan bahwa kebijakan yang diterapkan oleh pemerintah Kecamatan dikatakan berhasil. Karena jika diperhitungkan dari hasil porsentasi dari frekuensi yang ada pada rekapitulasi tabel dalam hal ini bersinggungan dengan upaya meningkatkan kualitas aparat porsentasinya berada diatas rata-rata.

\subsection{Saran}

1. Perlunya pengarahan, pembinaan, dan perhatian yang lebih dari pimpinan pada tingkat kedisiplinan aparatur. Karena hal ini sangat berpengaruh pula pada pelaksanaan kegiatan atau program yang memang sudah terapkan pada peraturan tentang apratur berdasarkan pada tuntutan realisasi pelaksanaan tugas pokok dan fungsi.

2. Diharapkan pada seluruh aparat yang ada di Kantor Kecamatan Bintauna, dalam hal pelayanan terhadap masyarakat harus terus dipertahankan bila perlu lebih ditingkatkan sampai pada batas kesempurnaan, Tanpa melihat strata. Karena dalam setiap dalam setiap gerak dan nafas suatu organisasi itu masyarakat selalu dan terus melekat.

\section{DAFTAR PUSTAKA}

Anderson, James E, Cases in public Policy Making, New York: Holt Rinerhart and Wiston, 1979

Barthos, Basir, Manajemen Sumber Daya Manusia: Suatu Pendekatan Makro, Bumi Aksara, Jakarta, 1990.

Bellone, Carl J., Ed., Organization Theory and The Public Andministration, Allyn and Bacon, Inc., Massachusetts, 1980. 
Bernandin, H. John, \& Joyce E.A. Russel, Human Resource Management, MacGraw-Hill, Inc., Singapore, 1993.

Dunn N. William, Pengantar Analisis Kebijakan Publik, Gadjah Mada University Press, Yogyakarta, 2003

Fathurrahman Deden dan Wawan Sobari. Pengantar ilmu politik, UMM Press, Malang, 2004

Kansil, Pengantar Ilmu Pemerintahan, PT. Eresco, Jakarta. 1991

Purwa Darminta W.J.S, Kamus Umum Bahasa Indonesia, Balai Pustaka, Jakarta. 1976.

Public Policy Making, New York: Holt, Rinerhart and Wiston, 2 nd edition, 1979.

Riggs Fred W, Administrasi Pembangunan, Sistem Administyrasi dan Birokrasi. Raja Grafindo 1996.

Santoso Prio Budi, Birokrasi pemerintahan Orde Baru - Prespektif Kultural dan Stuktural, PT. Raja Grafindo Persada, Jakarta, 1997.

Tilaar H.A.R Agenda Reformasi Pendidikan Nasioanal, Indonesia Tera.Jakarta 2001 